\title{
Effect of Kandangan Pump House on Long Storage Diversi Gunungsari in Sememi
}

\author{
Retsadika Kusriardi, Adi Prawito and Farida Hardaningrum \\ Faculty of Engineering \\ Civil Engineering Study Program \\ Narotama University Surabaya \\ Jl. Arif Rahman Hakim 51 Surabaya \\ retsa.pematusan@gmail.com, adi.prawito@narotama.ac.id, farida.hardaningrum@narotama.ac.id
}

\begin{abstract}
The Surabaya City Government has built a box culvert in the Gunungsari Diversi channel for the Sememi segment to Banjar Sugihan and the Kandangan pump house. The purpose of this study is to describe and analyze the operational impact of the Kandangan pump on the Sememi box culvert capacity.

Therefore, the Surabaya City Government built the Sememi box culvert as a long storage in the primary channel of the Gunungsari diversion in order to reduce inundation as well as function as a road that can overcome congestion in the area. The Surabaya City Government has also built a Kandangan pump house as an outlet rather than a long storage at the Gunungsari version. The reduction of inundation and congestion can increase the wheels of the economy which have a global impact on cities around Surabaya as well as a smoother access road for the people in West Surabaya to the middle of the city.
\end{abstract}

\section{Keywords:}

Drainage, Long Storage, Box Culvert, Pump House, Flood.

\section{Introduction}

\subsection{Research Background}

Inundation is an event when an area is filled with water because there is no drainage that breaks the water out of the area (Achmad Sobirin, 2007). Inundation often occurs in the West Surabaya area. In the last few years, Sememi Village, Benowo Sub-district has never been spared from waterlogging. The area of Kelurahan Sememi Surabaya has a lower contour than the area in the south, namely Lakarsantri Village, so that when it rains with high intensity, water from higher areas in the south will go straight to Sememi and cause puddles at some points.

Infrastructure development such as box culverts is one solution to overcoming inundation and flooding in West Surabaya. Sememi area, Benowo is one of the connecting routes to West Surabaya with Gresik City and Jalan Lintas Krian, Sidoarjo. In overcoming the congestion and inundation problems that occurred in West Surabaya, the Surabaya City Government constructed a box culvert in the Gunungsari Diversi channel, Sememi segment to Banjar Sugihan and the Kandangan pump house. The purpose of this study was to describe and analyze the operational impact of the Kandangan pump on the Sememi box culvert capacity.

Therefore, the Surabaya City Government built the Sememi box culvert as a long storage in the primary channel of the Gunungsari diversion in order to reduce inundation as well as function as a road that can overcome congestion in the area. The Surabaya City Government has also built a Kandangan pump house as an outlet rather than a long storage at the Gunungsari version.

Reducing inundation and congestion can increase the wheels of the economy which have a global impact covering cities around Surabaya as well as a smoother access road for people in West Surabaya to the middle of the city.

\subsection{Problem Formulation}

1) What is the planned flood discharge included in Sememi's long storage?

2) What is the existing capacity, the capacity of the Sememi Box Culvert long storage and the Kandangan primary channel?

3) How is the operation of the Kandangan pump house with the Sememi long storage that has been built? 


\section{Literature Review}

Based on the results of research conducted by (Cahyaningsih et al., 2016) which conducted research on long storage planning to implement a short-term flood control system that aims to slow down the peak flood time so that the flood discharge does not come simultaneously and will provide a flood reduction effect in the downstream and as water storage for the surrounding area.

Based on the results of research conducted by (Rahmananta, 2017). The downstream area of Kali Kandangan around Tambak Langon road, Asem Rowo District, is often inundated by floods, both from tides of sea water and rainwater that cannot flow into the river due to the relatively flat topography of the area. In addition, there have been changes in land use from ponds and waters to industrial areas so that the impermeable land increases.

To overcome this problem, a boezem will be planned to temporarily accommodate rainwater runoff when the elevation of the Kandangan river is higher and its disposal system. The return rain period used is 10 years and the assumption of 4 hours of rain. By using a rational method to calculate the volume of boezem required. Flood tracking to ascertain what pump capacity and door dimensions are required for the exhaust system.

The results of the planning resulted in a flood discharge in the Kali Kandangan sub-watershed of $9.42 \mathrm{~m} 3$ / second so that it requires an area of $30762 \mathrm{~m} 2$ with a depth of 3 meters. Boezem is equipped with a 2 pump exhaust system with a capacity of $1.05 \mathrm{~m} 3 / \mathrm{s}$ each and 2 doors with dimensions of 1 meter x 0.6 meter.

\section{Research Method}

\subsection{Data Source}

The data used in this study were sourced from the reports of the relevant contractors and consultants as well as from the relevant Dinas. In addition, literature study is also carried out by collecting and studying books, reports, journals and other literature related to the titles discussed in this study as well as data resulting from field surveys and interviews with communities around the research location which are more or less needed. as reference.

\subsection{Research Methodology}

Rainfall calculation using:

Algebra Average Method

Formula : $\bar{R}=1 / n\left(R_{1}+R_{2}+\ldots \ldots+R_{n}\right)$

The Thiessen Polygon Method

Formula : $W=\frac{A_{i}}{A_{\text {total }}}$

Calculation of the distribution of rainfall using:

Gumbel Method

Formula : $P(X \leq x)=e^{(-e)^{-y}}$

Pearson Log III

Formula : $P(X)=\frac{1}{(a) \Gamma(b)}\left[\frac{X-c}{a}\right]^{b-1} \cdot e^{-\left[\frac{X-c}{a}\right]}$

Normal

Formula : $P(X)=\frac{1}{\sigma \sqrt{2 \pi}} \cdot e^{-\frac{1}{2}\left[\frac{X-\mu}{\sigma}\right]^{2}}$

Normal Log

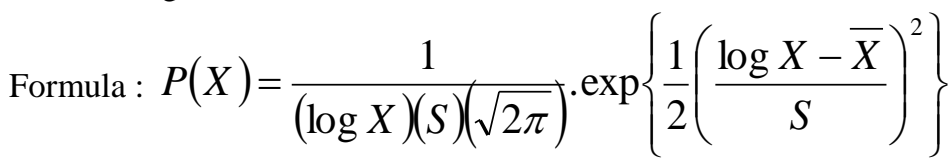

Rainfall calculation plans use:

Rational Method

Formula: $\mathrm{Q}=0.278$. C. It. A

Weduwen method

Formula: Qn $=\alpha . \beta$. q n. A

Hasper method 
Formula: $\mathrm{Qi}=\alpha . \beta . \mathrm{A} . \mathrm{qt}$

Channel capacity calculation using:

Pump Capacity Calculation

Formula: $\mathrm{Q}=\mathrm{A}$. V

Calculation of pump capacity using:

Pump Analysis

Formula: $\mathrm{Qp}=\mathrm{Qmax}-[(2 \mathrm{x} \mathrm{Qmax} x \mathrm{Vt}) / \mathrm{ntc}]^{\wedge} 0.5$

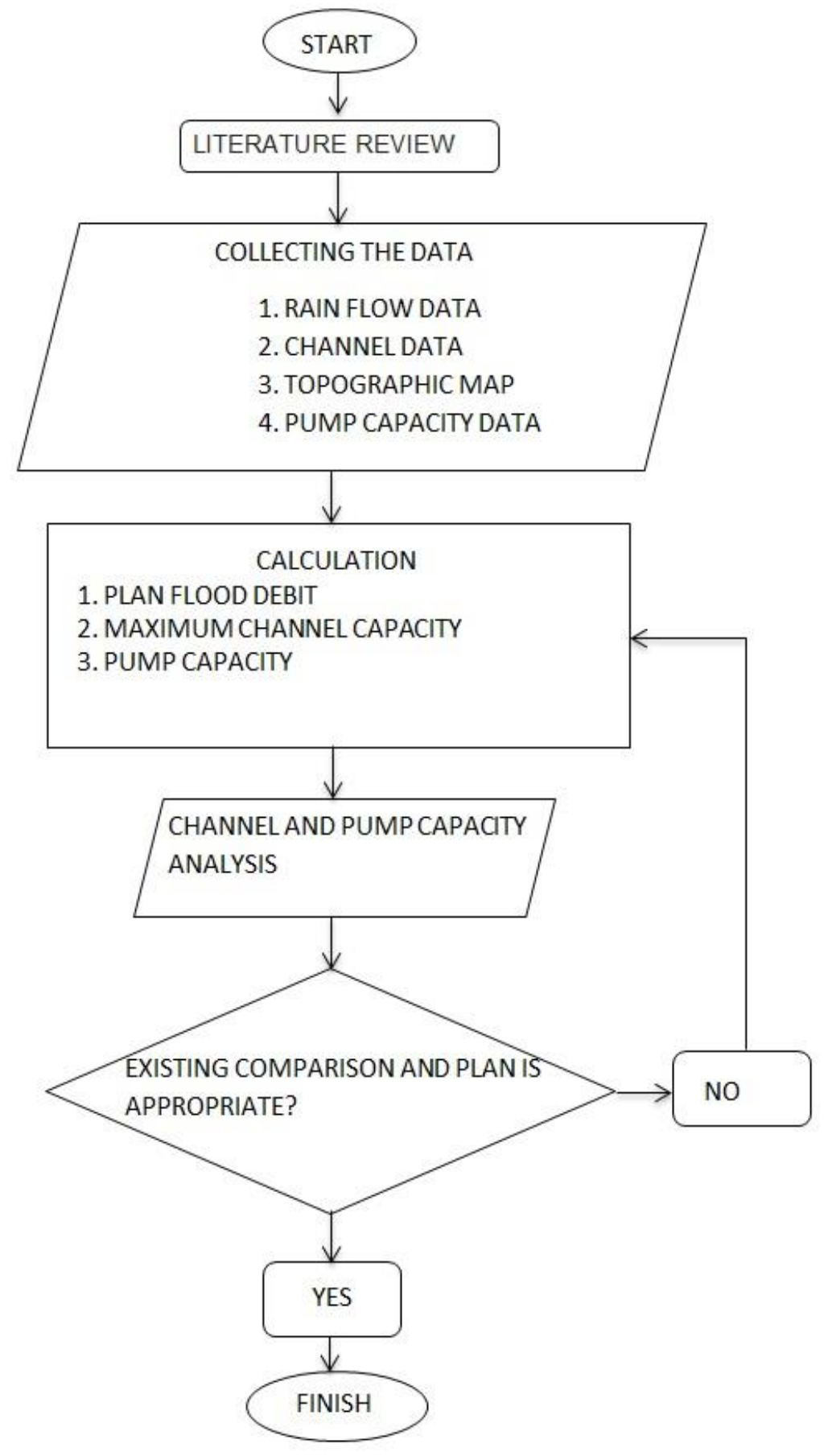




\section{Result And Discussion}

Tabel 1. Kandangan Station Rainfall Data

\begin{tabular}{cccc}
\hline No & Year & $\begin{array}{c}\text { Maximum Rainfall } \\
(\mathrm{mm})\end{array}$ \\
& & Channel & Average \\
\hline 1 & 2008 & 5,18 & 5,18 \\
2 & 2009 & 5,76 & 5,76 \\
3 & 2010 & 8,63 & 8,63 \\
4 & 2011 & 5,58 & 5,58 \\
5 & 2012 & 4,47 & 4,47 \\
6 & 2013 & 6,46 & 6,46 \\
7 & 2014 & 5,54 & 5,54 \\
8 & 2015 & 5,01 & 5,01 \\
9 & 2016 & 9,89 & 9,89 \\
10 & 2017 & 4,85 & 4,85 \\
N= 10 & $\sum \mathrm{R}=$ & & 61,36157613 \\
\hline (Source: Calculation results from the Meteorology, Climatology and Geophysics Agency)
\end{tabular}

Tabel 2. Analysis of the planned discharge capacity

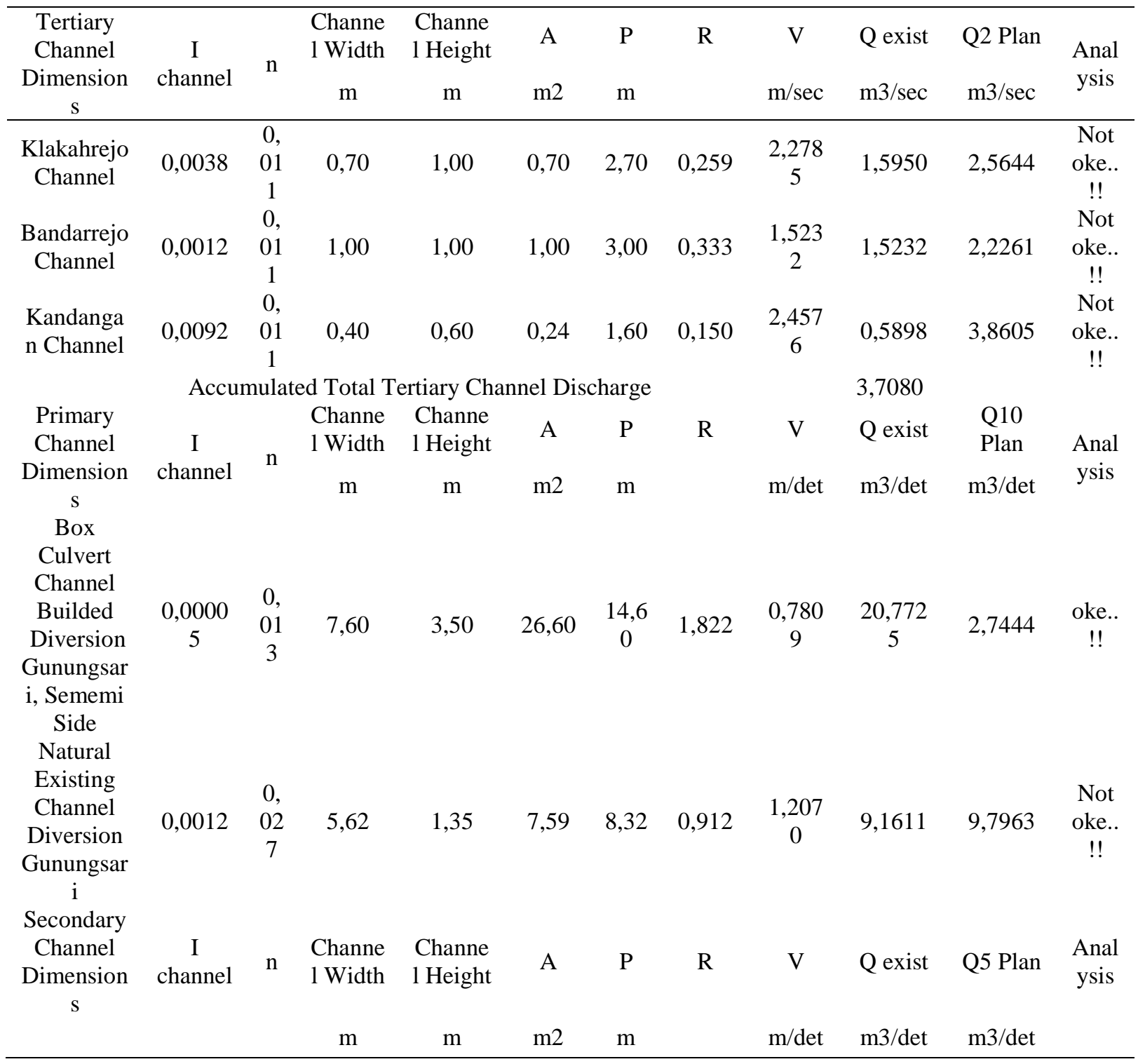


E-ISSN: 2685-3272 | P-ISSN 1412-0860

\begin{tabular}{ccccccccccccc}
\hline Bringin & 0,0009 & 0, & 02 & 5,00 & 1,50 & 7,50 & 8,00 & 0,938 & 1,065 & 7,9935 & 1,7825 & oke.. \\
Channel & 0 & 7 & & & & & & &
\end{tabular}

Primary Chan

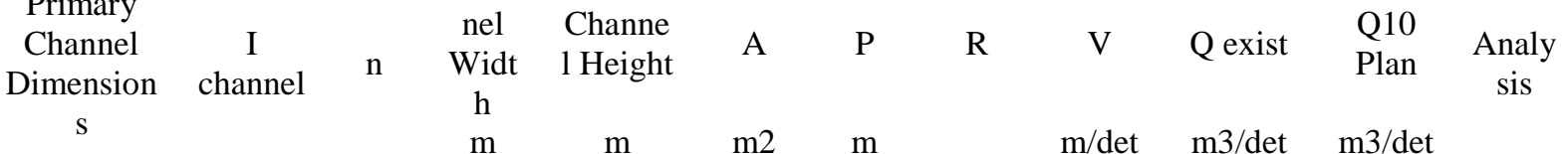

Box

Culvert

Channels $0,0006 \quad 0,01$

Manukan

$11,19 \quad 9,90 \quad 1,13$

2,057

23,0241

oke..!

Builded

Primary

Channel

Dimension

\begin{tabular}{ccccccccccc}
\multicolumn{1}{c}{$\begin{array}{c}\text { Chan } \\
\text { I }\end{array}$} & & Channe & & & & & & Q10 & Analy \\
channel & $\mathrm{n}$ & $\begin{array}{c}\text { Widt } \\
\mathrm{h}\end{array}$ & $\begin{array}{c}\text { 1 Height } \\
\mathrm{m}\end{array}$ & $\mathrm{A}$ & $\mathrm{P}$ & $\mathrm{R}$ & $\mathrm{V}$ & Q exist & $\begin{array}{c}\text { Plan } \\
\text { sis }\end{array}$ \\
& & & $\mathrm{m} 2$ & $\mathrm{~m}$ & & $\mathrm{~m} / \mathrm{det}$ & $\mathrm{m} 3 / \mathrm{det}$ & $\mathrm{m} 3 / \mathrm{det}$ &
\end{tabular}

Box

Culvert

Channels

Babat

$0,0001 \quad 0,01$

Jerawat

Builded

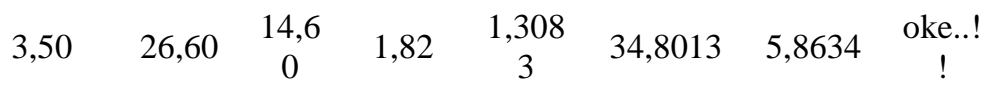

that enter the Sememi Channel $40 \%$

13,9205

\begin{tabular}{|c|c|c|c|c|c|c|c|c|c|c|c|}
\hline \multirow[t]{2}{*}{$\begin{array}{l}\text { Primary } \\
\text { Channel } \\
\text { Dimensions }\end{array}$} & \multirow[t]{2}{*}{$\begin{array}{c}\text { I } \\
\text { chann } \\
\text { el }\end{array}$} & \multirow[t]{2}{*}{$\mathrm{n}$} & \multirow{2}{*}{$\begin{array}{c}\text { Chan } \\
\text { nel } \\
\text { Widt } \\
\text { h } \\
\text { m }\end{array}$} & $\begin{array}{c}\text { Channel } \\
\text { Height }\end{array}$ & A & $\mathrm{P}$ & $\mathrm{R}$ & V & Q exist & $\begin{array}{l}\text { Q10 } \\
\text { Plan }\end{array}$ & \multirow[t]{2}{*}{$\begin{array}{c}\text { Analys } \\
\text { is }\end{array}$} \\
\hline & & & & $\mathrm{m}$ & $\mathrm{m} 2$ & $\mathrm{~m}$ & & $\mathrm{~m} / \mathrm{det}$ & $\mathrm{m} 3 / \mathrm{det}$ & $\begin{array}{l}\mathrm{m} 3 / \\
\mathrm{det}\end{array}$ & \\
\hline $\begin{array}{c}\text { Kali } \\
\text { Kandangan } \\
\text { Channel }\end{array}$ & $\begin{array}{c}0,000 \\
2\end{array}$ & 0,027 & 7,00 & 2,50 & $\begin{array}{l}17 \\
50\end{array}$ & $\begin{array}{c}12,0 \\
0\end{array}$ & 1,46 & 0,7401 & 12,9511 & $\begin{array}{c}4,22 \\
93\end{array}$ & oke..!! \\
\hline
\end{tabular}

(Source: Calculation Results)

Table 3. Total Debits Accumulated in Sememi Channels

$\begin{array}{lc}\text { Channel } & \text { Debit }(\mathrm{Q}) \\ \text { Klakahrejo Channel } & 1,5950 \\ \text { Bandarrejo Channel } & 1,5232 \\ \text { Kandangan Channel } & 0,5898 \\ \text { Channels Babat Jerawat Builded } & 13,9205 \\ \text { Q Total } & 17,6285\end{array}$

Table 4. The accumulated amount of debit that was accommodated in the Kali Kandangan channel

\begin{tabular}{cc}
\hline Channel & Debit (Q) \\
\hline Box Culvert Channels Gunungsari Diversion Sememi Side & 17,6285 \\
Bringin Channel & 7,9935 \\
Box Culvert Channels Manukan Builded & 23,0241 \\
Q Total & 48,6462 \\
\hline
\end{tabular}

(Source: Calculation Results)

This work is licensed under a Creative Commons Attribution-ShareAlike 4.0 International License. 
Table 5. Analysis of channel capacity

\begin{tabular}{cccc}
\hline Channel & Q Existing & Q In & Analysis \\
\hline & & & \\
Box Culvert Channels Gunungsari Diversion Sememi Side & 20,7725 & 17,6285 & oke..!! \\
Natural Existing Channel Diversion Gunungsari & 9,1611 & 17,6285 & not oke..!! \\
Kali Kandangan Channel & 12,9511 & 48,6462 & Not oke...!! \\
\hline
\end{tabular}

(Source: Calculation Results)

Table 6. Proposed calculation of dimensional change if normalization or further development is carried out.

\begin{tabular}{|c|c|c|c|c|c|c|c|c|c|c|c|}
\hline $\begin{array}{c}\text { Tertiary } \\
\text { Channel } \\
\text { Dimensions }\end{array}$ & $\begin{array}{c}\text { I } \\
\text { Channel }\end{array}$ & $\mathrm{n}$ & $\begin{array}{c}\text { Channel } \\
\text { Width } \\
\text { m }\end{array}$ & $\begin{array}{c}\text { Channel } \\
\text { High } \\
\text { m }\end{array}$ & $\begin{array}{l}\mathrm{A} \\
\mathrm{m} 2\end{array}$ & $\begin{array}{l}\mathrm{P} \\
\mathrm{m}\end{array}$ & $\mathrm{R}$ & $\begin{array}{c}\mathrm{V} \\
\mathrm{m} / \mathrm{d} \\
\text { et }\end{array}$ & $\begin{array}{c}\mathrm{Q} \\
\text { Existi } \\
\mathrm{ng} \\
\mathrm{m} 3 / \mathrm{de} \\
\mathrm{t}\end{array}$ & $\begin{array}{c}\text { Q2 } \\
\text { Plan } \\
\text { m3/det }\end{array}$ & $\begin{array}{l}\text { Analys } \\
\text { is }\end{array}$ \\
\hline $\begin{array}{c}\text { Klakahrejo } \\
\text { Channel }\end{array}$ & 0,0038 & $\begin{array}{c}0,01 \\
3\end{array}$ & 1,00 & 1,20 & $\begin{array}{c}1,2 \\
0\end{array}$ & $\begin{array}{c}3,4 \\
0\end{array}$ & $\begin{array}{c}0,3 \\
53\end{array}$ & $\begin{array}{c}2,36 \\
82\end{array}$ & $\begin{array}{c}2,841 \\
8\end{array}$ & 2,5644 & oke..!! \\
\hline $\begin{array}{c}\text { Bandarrejo } \\
\text { Channel }\end{array}$ & 0,0012 & $\begin{array}{c}0,01 \\
3\end{array}$ & 1,20 & 1,50 & $\begin{array}{c}1,8 \\
0\end{array}$ & $\begin{array}{c}4,2 \\
0\end{array}$ & $\begin{array}{l}0,4 \\
29\end{array}$ & $\begin{array}{c}1,52 \\
39\end{array}$ & $\begin{array}{c}2,743 \\
1\end{array}$ & 2,2261 & oke..!! \\
\hline $\begin{array}{c}\text { Kandangan } \\
\text { Channel }\end{array}$ & 0,0092 & $\begin{array}{c}0,01 \\
3\end{array}$ & 1,00 & 1,20 & $\begin{array}{c}1,2 \\
0\end{array}$ & $\begin{array}{c}3,4 \\
0\end{array}$ & $\begin{array}{l}0,3 \\
53\end{array}$ & $\begin{array}{c}3,67 \\
88\end{array}$ & $\begin{array}{c}4,414 \\
6\end{array}$ & 3,8605 & oke...!! \\
\hline $\begin{array}{c}\text { Primary } \\
\text { Channel } \\
\text { Dimensions }\end{array}$ & I saluran & $\mathrm{n}$ & $\begin{array}{c}\text { Effectiv } \\
\text { e } \\
\text { Channel } \\
\text { Width } \\
\text { m }\end{array}$ & $\begin{array}{c}\text { High } \\
\text { Effective } \\
\text { Channel }\end{array}$ & $\mathrm{m} 2$ & $\mathrm{~m}$ & $\mathrm{R}$ & $\begin{array}{c}\mathrm{m} / \mathrm{d} \\
\text { et }\end{array}$ & $\begin{array}{c}\mathrm{Q} \\
\text { Existi } \\
\mathrm{ng} \\
\mathrm{m} 3 / \mathrm{de} \\
\mathrm{t}\end{array}$ & $\mathrm{m} 3 /$ det & $\begin{array}{c}\text { Analys } \\
\text { is }\end{array}$ \\
\hline $\begin{array}{c}\text { Kali } \\
\text { Kandangan } \\
\text { Channel }\end{array}$ & 0,0002 & $\begin{array}{c}0,02 \\
7\end{array}$ & 11,00 & 4,50 & $\begin{array}{l}49 \\
50\end{array}$ & $\begin{array}{l}20 \\
00\end{array}$ & $\begin{array}{c}2,4 \\
8\end{array}$ & $\begin{array}{c}1,05 \\
30\end{array}$ & $\begin{array}{c}52,12 \\
18\end{array}$ & $\begin{array}{c}48,646 \\
2\end{array}$ & oke..!! \\
\hline
\end{tabular}

(Source: Calculation Results)

\section{Conclusion And Suggestions}

From the results of the analysis in this final project, it can be concluded that:

1. The cause of flooding in the Sememi area is the capacity of the existing natural Gunungsari Diversion Primary channel of $9.1611 \mathrm{~m} 3$ / second unable to accommodate the planned flood discharge of $9.7963 \mathrm{~m} 3 /$ second plus the accumulation of the planned discharge of the tertiary channel of $3.7080 \mathrm{~m} 3 /$ seconds leading to the primary channel of Gunungsari Diversion.

2. Flood control solution by constructing Box Culvert Diversi Gunungsari upstream Sememi to Kandangan outlet according to Q10 calculation of $20.7725 \mathrm{~m} 3$ / second is still able to accommodate flow from tertiary channels and part of Acne Bladder channels whose accumulation is $17.6285 \mathrm{~m} 3 /$ second .

3. The operation of the Kandangan pump house on the existing long storage can be said to be sufficient for the current accumulated pump capacity of $9.75 \mathrm{~m} 3$ / second, but after the construction of the Sememi box culvert to Acne Babat and Manukan to Banjar Sugihan, the accumulated discharge is 48, The resulting $6462 \mathrm{~m} 3 / \mathrm{s}$ cannot be used up with the existing pump.

\section{Suggestions}

To deal with the inundation that is working in the upstream area of Sememi and downstream of the Kandangan River, the following efforts should be made:

1. It is necessary to maintain and normalize the Kandangan river in order to obtain maximum capacity.

2. The construction of the Culvert Diversi Box with a large capacity and serves as a long storage for the Gunungsari Diversion before entering the Kandangan river.

3. Providing socialization to the community around the long storage flow so that they do not throw garbage into the river or the Culvert Box channel.

4. Construction of a village tertiary channel leading to the Sememi Channel, with concretization (u-ditch) so that a safe storage channel does not occur in the upstream area of the Sememi Channel.

5. Optimizing the operation and rejuvenation as well as increasing the capacity of the Kandangan pump in order to help reduce the discharge from the Diversi channel. 
6. Developing Boezem upstream and downstream of the Kandangan river in order to obtain temporary storage that can reduce flood discharge in the upstream Kandangan river.

\section{References}

Achmad Sobirin. (2007). Budaya organisasi : pengertian, makna, dan aplikasinya dalam kehidupan organisasi. UPP STIM YKPN. https://opac.perpusnas.go.id/DetailOpac.aspx?id=294238

Cahyaningsih, E., Ratri, R. C., Kurniani, D., \& Hary Budieny. (2016). Perencanaan Long Storage Jetis Kec Blora Kab Blora.$$
\text { KARYA }
$$$$
\text { TEKNIK }
$$

SIPIL,

$5(1)$. https://ejournal3.undip.ac.id/index.php/jkts/article/view/11770/11425

Rahmananta, H. F. (2017). Planning Of Boezem And Pumps In Downstream Area Of Kandangan River, West Surabaya. https://repository.its.ac.id/42815/1/3113100053-Undergraduate_Theses.pdf 